\title{
PRZEMIANY NARODOWOŚCIOWE W KRAJU KŁAJPEDZKIM W XX WIEKU
}

K raj (okreg) Kłajpedzki (po litewsku: Klaipédos Krästas, po niemiecku: Memelgebiet lub Memelland) jest położony nad Morzem Bałtyckim po północnej stronie Niemna. Przylega od zachodu do litewskiej Żmudzi. Powierzchnia tego terytorium rozciągającego się na długości 140 km i szerokości około $20 \mathrm{~km}$ liczy 2848 km². Historycznie stolicą tej prowincji była Kłajpeda, port często nazywany "litewskim Gdańskiem". Miasto to położone jest nad Zalewem Kurońskim przy ujściu rzeki Dange, która jest połączona kanałem z ujściem Niemna, leżącym 25 km na południe od Kłajpedy ${ }^{1}$.

Obecnie Kraj Kłajpedzki stanowi integralną część państwa litewskiego, ale jego dzieje polityczne były dość złożone. Dla Niemców jest to historyczna część Prus Wschodnich, należąca dawniej do Królestwa Pruskiego, a następnie do Cesarstwa Niemieckiego. Dla narodu litewskiego Kraj Kłajpedzki, wraz z całą północno-wschodnią częścią Prus Wschodnich leżącą po południowej stronie Niemna, to tzw. Mała Litwa (lit. Mažoji Lietuva). Są to według Litwinów rdzenne ziemie litewskie, które w wyniku stopniowej germanizacji miejscowej ludności stały się dopiero w pierwszej połowie XX w. narodowościowo niemieckie. Autochtoniczni mieszkańcy różnili się od Litwinów z tzw. Wielkiej Litwy wyznaniem. Nie byli katolikami, lecz protestantami, co zbliżało ich kulturowo i mentalnie do ludności nie-

Kraj Kłajpedzki obejmował oprócz miasta Kłajpedy 3 powiaty: Kłajpede (lit. Klaipéda, niem. Memel), Szyłokarczme (lit. Šiluté, niem. Haydekrug) oraz Pojegi (lit. Pagégiai, niem. Pogegen). W okresie międzywojennym podzielony był na 65 gmin (Amtsbetzierke), 30 osiedli miejskich oraz 551 wsi.
Prof. dr hab. Piotr EBERHARDT jest profesorem w Instytucie Geografii i Przestrzennego Zagospodarowania PAN w Warszawie. p.ebe@twarda.pan.pl 


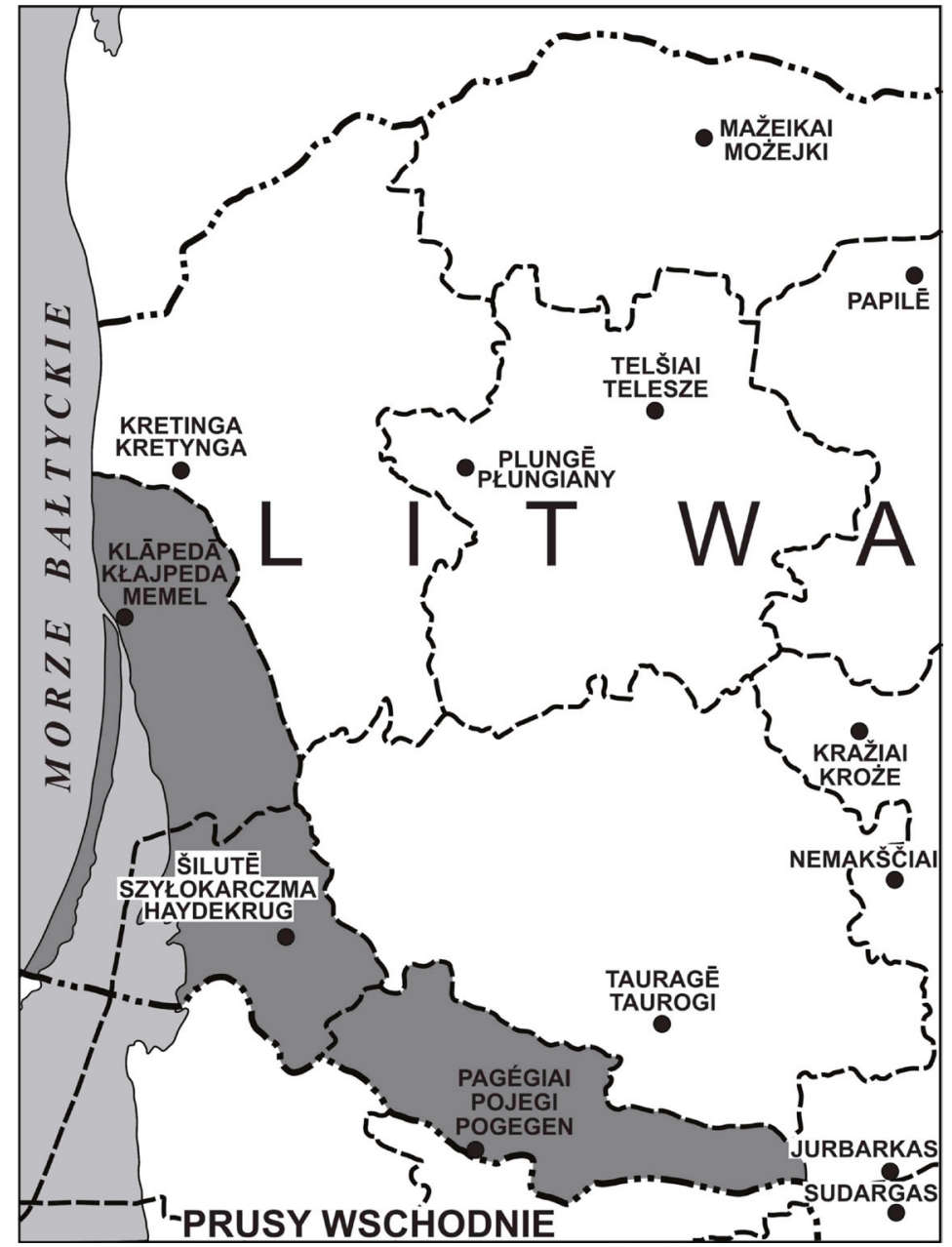

Kraj Kłajpedzki w okresie międzywojennym

mieckiej. Pierwotnie byli litewskojęzyczni, lecz w wyniku presji niemieckiej zatracali swoją odrębność językową. Procesy germanizacyjne zachodziły szybciej po południowej stronie Niemna. Po północnej stronie, w Kraju Kłajpedzkim, język litewski przetrwał aż do XX w., ale litewska świadomość narodowa miejscowej ludności nie była zbyt mocno ugruntowana. Zwłaszcza że była to niewykształcona ludność wiejska, gdyż w miastach, w tym również w Kłajpedzie, przeważała ludność języka i narodowości niemieckiej.

Pierwotnymi mieszkańcami tego regionu nadmorskiego byli przypuszczalnie Kuroni, plemię bałtyckie zbliżone językiem do Łotyszy. Według przyjętej hipotezy, ludność litewska napłynęła tu dopiero w XV-XVI w. po częściowym wytępieniu przez Krzyżaków nielicznej ludności pruskiej. Założony w 1254 r. krzyżacki zamek pod nazwą Memelburg stał się początkiem miasta Memel. Prowincja dzieliła następnie losy państwa krzyżackiego (do 1525 r.), Prus Książęcych (do 1701 r., w tym do 1657 r. w zależności lennej do Polski), Królestwa Pruskiego (do 1871 r.) i Cesarstwa Niemieckiego (do 1919 r.). 
W drugiej połowie XIX w. Mała Litwa odegrała niezmiernie istotną rolę w odrodzeniu litewskiej świadomości narodowej. Wpłynęły na to ówczesne uwarunkowania polityczne. Ziemie litewskie po upadku Rzeczypospolitej znalazły się w granicach imperium rosyjskiego. Miejscowa szlachta przyjęła opcję polską. Władze rosyjskie prowadziły akcję depolonizacyjną, równocześnie uniemożliwiały działania na rzecz litewskiego odrodzenia narodowego (między innymi obowiązywał zakaz wydawania druków litewskich w transkrypcji łacińskiej). Po drugiej stronie granicy, w Prusach Wschodnich, nie było tego typu ograniczeń. Wyższy poziom cywilizacyjny sprzyjał też rozwojowi kultury litewskiej. Nic więc dziwnego, że Mała Litwa stała się „Piemontem” odrodzenia świadomości narodowej Litwinów. Zwłaszcza że na tzw. pruskiej Litwie były już tradycje działalności wydawniczej w języku litewskim. Tu bowiem wydano pierwszą litewską książkę (1574 r.), przełożono na język litewski Pismo Święte (1590 r.), opublikowano pierwszą książkę z zakresu literatury pięknej (1706 r.) i ukazała się pierwsza gazeta w języku litewskim (1822 r.). Dlatego też istniały warunki do pojawienia się na tzw. pruskiej Litwie grupy działaczy zmierzających do rozbudzenia litewskiej świadomości narodowej. Dzięki ich inicjatywie powstało w 1883 r. czasopismo "Auszra"2. Choć większość jego redaktorów pochodziła z Wielkiej Litwy, czyli zaboru rosyjskiego, to bez wsparcia miejscowych Litwinów pismo nie mogłoby odegrać tak ważnej roli w procesie kształtowania się nowoczesnego narodu litewskiego. Równocześnie trwały na tzw. pruskiej Litwie intensywne procesy germanizacyjne. Władze niemieckie rozpoczęły akcję rugowania języka litewskiego. Ustawa państwowa z 1876 r. ogłosiła język niemiecki jako jedyny język urzędowy. Stopniowo likwidowano szkoły litewskie. Dużą rolę w germanizacji odegrał Kościół protestancki, który zwalczał separatyzm i umacniał istniejące tendencje lojalistyczne wobec władzy niemieckiej wśród litewskojęzycznych mieszkańców.

O zmniejszeniu się liczby ludności litewskiej dowodziły kolejne spisy ludności. Według danych z 1849 r. Litwinów mówiących tylko po litewsku było w Prusach Wschodnich 137,0 tys., a w roku 1890 - 114,9 tys. (S. Szostakowski 1992, s. 12). W literaturze przedmiotu podawane są różne wyliczenia. Na przykład dla 1867 r. podawano liczbę 36,0 tys. Litwinów zamieszkałych w rejencji królewieckiej i 111,0 tys. w rejencji gąbińskiej. Oficjalnie dane spisu niemieckiego z 1900 r. wykazały w Prusach Wschodnich 106,2 tys. ludności litewskojęzycznej, zaś kolejny spis z 1910 r. - jedynie 89,9 tys. Większość z nich, bo aż 68,7 tys., zamieszkiwało Kraj Kłajpedzki³. Liczył on wówczas 141,0 tys. mieszkańców. Połowa z nich $(48,7 \%)$ uznała litewski za swój język ojczysty. Byli to głównie mieszkańcy wsi, gdyż w samej Kłajpedzie tylko 9,2\% jej mieszkańców posługiwało się w życiu codziennym językiem litewskim. Dane te przypuszczalnie zaniżały faktyczną liczbę ludności używającej tego języka. W rzeczywistości język litewski był bardziej rozpowszechniony. Z drugiej jednak strony wśród ludności używającej języka litewskiego świadomość ich łączności z narodem litewskim była dość powierzchowna. Nie wnikając w rozbieżne dane statystyczne publikowane przez władze pruskie, bardziej obiektywne oceny badaczy też potwierdzały skuteczność realizowanej polityki germanizacyjnej na etnicznych obszarach litewskich. Obszar zamieszkany przez Litwinów kurczył się z generacji na generację.

O roli Małej Litwy w powstaniu nowoczesnego narodu litewskiego, w tym o znaczeniu czasopisma "Auszra”, wychodzącego w Prusach Wschodnich i rozpowszechnianego na terenie zaboru rosyjskiego, źródłowy artykut napisał S. Szostakowski (1992, s. 9-26).

3 Wiele informacji o stosunkach narodowościowych na tzw. Małej Litwie oraz o kurczeniu się litewskiego obszaru etnicznego w Prusach Wschodnich zawierają książki W. Wielhorskiego $(1932,1938)$ oraz S. Srokowskiego (1929, 1937). 
Zwłaszcza miało to miejsce na terenach położonych na południe od Niemna ${ }^{4}$. W Kraju Kłajpedzkim sytuacja była korzystniejsza, gdyż tam tylko miasta były niemieckie, zaś na obszarach wiejskich aż do I wojny światowej ludność posługiwała się w życiu codziennym językiem litewskim. Nie znaczy to, że deklarowała narodowość litewską. Identyfikowała się z własnym regionem i odczuwała zarówno wobec protestanckich Niemców, jak i katolickich Litwinów wyraźną odrębność kulturową.

Do końca I wojny światowej problem kłajpedzki nie istniał w polityce europejskiej. Dopiero w chwili klęski kajzerowskich Niemiec ujawniła się grupa działaczy litewskich z Małej Litwy. Powołali oni 16 XI 1918 r. Narodową Radę Litewską w Prusach. Podjęła ona 30 XI 1918 r. uchwałę o zjednoczeniu Małej Litwy z Wielką Litwą, przy przyznaniu tej pierwszej szerokiej autonomii terytorialnej. Następnym krokiem Narodowej Rady Litewskiej było wystosowanie w dniu 6 II 1919 r. memoriału do przedstawicieli zwycięskich mocarstw obradujących na konferencji paryskiej w Wersalu. Domagano się w nim oderwania od Prus Wschodnich etnicznych obszarów litewskich. Apel ten był następnie skonkretyzowany przez rząd Litwy, który 15 IV 1919 r. określił swoje postulaty terytorialne. Litwini zażądali nie tylko przyłączenia do Litwy Kraju Kłajpedzkiego, lecz również obszarów położonych po południowej stronie Niemna aż po linię Łabiawa - Wystruć - Darkejmy Gołdap. Dezyderaty litewskie zostały wówczas poparte przez delegację polską, głównie przez Romana Dmowskiego. Przedstawiciele Ententy odrzucili tak daleko idące żądania terytorialne. Niemniej, w ostatecznym werdykcie Kraj Kłajpedzki został odłączony od państwa niemieckiego. Podjęto decyzję o wytyczeniu granicy niemiecko-litewskiej nurtem rzeki Niemen. Na podstawie postanowień traktatu wersalskiego zostało odłączone od Niemiec całe terytorium położone po północnej stronie Niemna wraz z miastami Kłajpeda i Szyłokarczma, obejmujące, jak zaznaczono, 2848 km².

Według powojennego spisu ludności z 30 IX 1920 r. znajdowało się na nim 150746 mieszkańców. Język niemiecki zadeklarowało 71,0 tys., zaś litewski 67,0 tys. spisywanych. Zdecydowanie przeważali protestanci (132,0 tys.). Do wyznania katolickiego przyznało się jedynie 5383 osób, zaś ludność żydowska była również nieliczna - 1350 osób (P. Łossowski 2007, s. 20).

Ostatecznie okręg kłajpedzki nie został włączony w skład państwa litewskiego. Władzę lokalną utrzymali miejscowi Niemcy, zaś kuratelę nad całym okręgiem sprawowali alianci zachodni. Wyrazem tej władzy był oddział francuski, który przybył do Kłajpedy w celu zachowania istniejącego status quo, czyli stanu tymczasowego. Okręg kłajpedzki został odłączony od Niemiec, lecz nie stanowił integralnej części Litwy. W związku z tym władze kowieńskie zainicjowały próby zintegrowania Kraju Kłajpedzkiego z nowo powstałym państwem litewskim. Przyjęto między innymi 21 III 1920 r. rezolucję, w której proponowano dokooptowanie przedstawicieli Kłajpedy do Litewskiej Taryby urzędującej w Kownie. Oficjalnie głoszono, że Kraj Kłajpedzki stanowi część Litwy i dysponuje autonomią samorządową. Nie wywarło to jednak dużego wpływu na dalszy tok wydarzeń. Nadal w Kłajpedzie przebywał garnizon francuski. Świadczyło to ciągle o stanie tymczasowo-

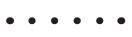

4 Według danych z początków XVIII W., a mianowicie z 1719 r., cała północno-wschodnia część Prus Wschodnich była etnicznie litewska. Takie powiaty, jak: Stołupiany, Gąbin, Wystruć, Piłkale, Regneta, Tylża, Niziny oraz Szyłokarczma i Kłajpeda były zamieszkane przez ludność litewskojęzyczną. Cofanie się na północ żywiołu litewskiego tłumaczy W. Wielhorski w sposób następujący "Szczególnie otoczenie przez Prusy opieką finansową rolnictwa krajowego miało niewątpliwie, obok zjawisk ogólnokulturalnych, wpływ wybitny na mocniejsze związanie litewskiej ludności wiejskiej z niemieckością. Stwarza to warunki do krzewienia się poczucia państwowego pruskiego i stwarza podatne podłoże, by wpływ szkoły niemieckiej, wojska niemieckiego i protestanckiego Kościoła niemieckiego, wspólnego dla obu narodowości, przeprowadzał młodsze pokolenia Litwinów do szeregów patriotów pruskich z językiem domowym już niemieckim" (W. Wielhorski 1932, s. 35-36). 
ści i braku ostatecznej decyzji zachodnich aliantów. Strona niemiecka zaczęła sprzyjać stronie litewskiej. Niemcy obawiali się, że alianci utworzą Wolne Państwo Kłajpedzkie, które będzie pod wyłączną kontrolą Francji. Związanie zaś Kłajpedy z Litwą, państwem słabym politycznie, dawało Niemcom większą szansę dokonania aneksji w bliższej lub dalszej perspektywie. Władze litewskie też były coraz bardziej zdeterminowane i zainteresowane zlikwidowaniem istniejącego status quo. Rozpoczęto przygotowania militarne do „wyzwolenia” i włączenia Kraju Kłajpedzkiego do Wielkiej Litwy. Zorganizowano grupy paramilitarne, które 10 | 1923 r. przekroczyły granicę i zajęły część Kraju Kłajpedzkiego. Działo się to przy pełnej bierności miejscowej ludności. Władze litewskie wskazywały, że jest to niezależna akcja powstańcza, niemająca poparcia rządu kowieńskiego. Po opanowaniu całej prowincji oddziały litewskie wkroczyły do Kłajpedy. Napotkały opór garnizonu francuskiego. W toku walk poległo kilku żołnierzy francuskich i kilkunastu „powstańców” litewskich. Zajęcie Kłajpedy przez Litwinów wywołało poważne perturbacje międzynarodowe. Mocarstwa zachodnie zaprotestowały energicznie i postawiły sprawe wkroczenia oddziałów litewskich do Kłajpedy na forum tzw. Komisji Ambasadorów, która utworzyła odpowiednią komisję. Do portu kłajpedzkiego wpłynęły wojenne okręty francuskie i angielskie. Strona litewska została zmuszona do rokowań politycznych. Obie strony były zainteresowane kompromisem, gdyż obawiały się eskalacji działań militarnych. Ostateczna decyzja była korzystna dla Litwinów. Na podstawie tzw. konwencji paryskiej z dnia 28 V 1924 r. przekazano Litwie suwerenność nad Krajem Kłajpedzkim. Garnizon francuski opuścił Kłajpedę, zaś Litwa zobowiązała się do zachowania wolnego tranzytu handlowego i zawarcia konwencji respektującej prawa obywatelskie miejscowej ludności. Strona niemiecka przyjęła ten werdykt z zadowoleniem, gdyż obawiała się, że nieunormowany status prowincji może być wykorzystany przez Polske do okrążenia militarnego i gospodarczego Prus Wschodnich ${ }^{5}$.

Litwini potraktowali to jako swój wielki sukces prestiżowy i militarny. Poprzez przyłączenie Kraju Kłajpedzkiego, pomimo licznych ograniczeń formalnych, uzyskali jednak port morski, który otwierał im możliwości bezpośredniego kontaktu ze światem. Zmuszeni byli przyjąć żądanie powołania autonomicznej władzy administracyjnej ulokowanej w Kłajpedzie. Władze litewskie musiały również uznać język niemiecki za język pełnoprawny z litewskim.

Bezpośrednio po tych wydarzeniach politycznych w Kraju Kłajpedzkim w 1925 r. zrealizowano spis ludności. Ostateczne wyniki były dość niejednoznaczne. Ujawniono w nim 141,0 tys. mieszkańców, z których 61,3 tys. (43,5\%) podało jako ojczysty język niemiecki, 38,9 tys. (27,6\%) - litewski, 35,6 tys. (25,2\%) - kłajpedzki. Pozostali, w liczbie 5,2 tys. $(3,7 \%)$, wskazali na inne języki6.

Rezultaty te zostały odmiennie zinterpretowane przez demografów niemieckich i litewskich. Dotyczyło to przynależności narodowej osób deklarujących język "kłajpedzki”. Wiadomo, że taki język nie istniał. Podały go przeważnie osoby używające języka litewskiego, gdyż mieszkańcy posługujący się niemieckim nie wskazywali języka „kłajpedzkiego". Język litewski bądź „kłajpedzki” podawali mieszkańcy wsi, gdyż tam zachował się

\section{$\cdots \cdots$}

5 Stanowisko Polski do zamachu litewskiego z lutego 1923 r. było dość bierne i wyczekujące. Rząd Polski ograniczył się do złożenia noty protestacyjnej przeciw pogwałceniu przez Litwę traktatu wersalskiego, gwarantującego na tym terytorium zwierzchnictwo mocarstw zachodnich. Starano się jedynie zagwarantować ułatwienia tranzytowe przez port kłajpedzki dla polskich towarów. Przez niektórych polityków polskich pasywna postawa była oceniana jako błąd naszej dyplomacji. Uważano, że poprzez bardziej ekspansywną politykę Polska mogłaby być jednym z sygnatariuszy układu zapewniającego kuratelę nad tym spornym obszarem (W. Staniewicz 1924, s. 32)

6 Spis ten został skomentowany przez autora w jego książce poświęconej przemianom narodowościowym na Litwie (P. Eberhardt 1997, s. 110). 
miejscowy dialekt litewski. Mieszkańcy miast w przeważającej większości wskazywali na niemiecki jako swój język ojczysty. Dane spisowe nie upoważniają w pełni do wniosków dotyczących narodowości. Wskazano już, że u ludności litewskojęzycznej wyznania protestanckiego istniały mocno artykułowane sympatie proniemieckie i nieufność do nowego państwa litewskiego.

Nieustabilizowana sytuacja polityczna w latach 20. była przyczyną ruchów migracyjnych. Z okręgu kłajpedzkiego do Niemiec wyjechało 7,1 tys. Niemców. W tym samym czasie z Litwy napłynęło około 8,0 tys. rdzennych Litwinów, wśród tych ostatnich było wielu pracowników umystowych skierowanych do lokalnej administracji.

Władze litewskie przystąpiły w końcu lat 20. do celowych działań zmierzających do lituanizacji prowincji. Zaczęto wprowadzać język litewski do urzędów i szkół. Przywracano stare nazewnictwo litewskie w miejsce niemieckiego oraz ograniczano prawa przedstawicielskie miejscowej ludności na rzecz administracji powołanej przez władze centralne. Preferowanie przyjezdnych Litwinów przy obsadzaniu stanowisk napotykało zdecydowany opór nie tylko Niemców, ale też mieszkańców litewskojęzycznych7. O nastawieniu miejscowej ludności świadczą wyniki wyborów do miejscowego ciała przedstawicielskiego (sejmiku). Na listy niemieckie głosowała przeważająca większość miejscowej ludności. Listy litewskie uzyskiwały jedynie kilkanaście procent poparcia, gdy tymczasem dwa największe ugrupowania niemieckie uzyskiwały bezwzględną większość i one też zdobywały najwięcej mandatów oraz możliwości współrządzenia (Tabela 1).

Tabela 1. Wyniki wyborów do sejmiku kłajpedzkiego w okresie międzywojennym

\begin{tabular}{|l|r|r|r|r|r|r|}
\hline \multirow{3}{*}{ Ugrupowania polityczne } & \multicolumn{6}{|c|}{ Liczebność wyborców } \\
\cline { 2 - 7 } & \multicolumn{2}{|c|}{1924} & \multicolumn{2}{c|}{1930} & \multicolumn{2}{c|}{1932} \\
\cline { 2 - 7 } & \multicolumn{1}{|c|}{ ogółem } & \multicolumn{1}{c|}{$\%$} & \multicolumn{1}{c|}{ ogółem } & \multicolumn{1}{c|}{$\%$} & \multicolumn{1}{c|}{ ogółem } & \multicolumn{1}{c|}{$\%$} \\
\hline Niemiecka partia rolnicza & 18355 & 37,2 & 15215 & 32,7 & 24442 & 37,3 \\
\hline Niemiecka partia ludowa & 14455 & 29,2 & 13669 & 29,4 & 17992 & 27,4 \\
\hline Listy litewskie & 7144 & 14,5 & 8804 & 18,9 & 12624 & 19,3 \\
\hline Komuniści & 3882 & 7,9 & 2062 & 4,4 & 5390 & 8,2 \\
\hline Socjaldemokraci & 5502 & 11,1 & 6780 & 14,6 & 5114 & 7,8 \\
\hline Ogółem & 49338 & 100,0 & 46530 & 100,0 & 65562 & 100,0 \\
\hline
\end{tabular}

Ż ró d † o: Jan Ochota, Zatarg litewsko-niemiecki w Kłajpedzie, "Sprawy Narodowościowe”, R. VI, nr 2-3, s. 277, Warszawa 1932.

Rezultaty wyborcze wskazywały, że władzom litewskim nie udało się pozyskać miejscowej ludności, która broniła swej odrębności i nadal była wierna niemieckim tradycjom politycznym. Litewskość nie była dla niej atrakcyjna. Otwarcie granicy z Litwą umożliwiło przyjazdy do pracy licznych robotników litewskich. Miały one początkowo charakter sezonowy, a następnie zaczęły się przekształcać w stałą pracę najemną. Napływający Litwini głównie osiedlali się w Kłajpedzie, gdyż rozwijający się port morski oferował miejsca zatrudnienia. Próby osadnictwa litewskiego na terenach wiejskich, pomimo usiłowań rządu kowieńskiego, zakończyły się niepowodzeniem.

Po dojściu Hitlera do władzy sytuacja w prowincji zaczęła się zaostrzać. Zaczęły powstawać organizacje separatystyczne mające na celu zmianę statusu prowincji. Równocześnie władze nazistowskich Niemiec uzyskiwały coraz silniejszą pozycję polityczną. Roz-

\section{......}

Kwestie te były na bieżąco omawiane w polskich czasopismach naukowych. Na uwagę szczególną zasługuje artykuł J. Ochoty (1932, s. 269-279), w którym dokładnie omówiono sytuację w Kraju Kłajpedzkim po włączeniu go do państwa litewskiego. 
poczęły się dyplomatyczne naciski na Litwę, domagano się od niej początkowo ustępstw, a następnie kapitulacjii. Miejscowa ludność zaczęła głośno domagać się przyłączenia do III Rzeszy. W przeprowadzonych wyborach do władz lokalnych w latach 30. listy litewskie uzyskiwały nadal jedynie kilkunastoprocentowe poparcie. Dało to Niemcom dodatkowe argumenty, gdyż władze przedstawicielskie znalazły się w rękach miejscowych Niemców.

Sytuacja międzynarodowa coraz bardziej sprzyjała Niemcom. Po opanowaniu czeskiej Pragi było już wiadomo, że następną ofiarą będzie Kraj Kłajpedzki ${ }^{9}$. W rezultacie wystosowanego ultimatum rządowa delegacja litewska udała się 22 III 1939 r. do Berlina. Następnego dnia został zawarty układ, w którym Litwa zrzekła się praw do Kraju Kłajpedzkiego i uznała jego przyłączenie do III Rzeszy Niemieckiej. Wiązało się to z natychmiastowym wycofaniem wojsk litewskich z całego obszaru przekazanego Niemcom. Na pokładzie pancernika "Deutschland” wpłynął 23 III 1939 r. osobiście Hitler do portu kłajpedzkiego. Towarzyszyło mu około 30 okrętów Kriegsmarine. W czasie kilkugodzinnego pobytu w Kłajpedzie Hitler uroczyście podpisał ustawę wprowadzającą na terenie całego Kraju Kłajpedzkiego ustawodawstwo III Rzeszy. Dokument stwierdzał, że "terytorium Kłajpedy jest częścią Rzeszy Niemieckiej" (S. Mikulicz 1976, s. 249)10.

Rząd litewski oficjalnie wyraził akceptację ultimatum i prezydent Litwy Antanas Smetona w dniu 1 IV 1939 r. dokonał ratyfikacji narzuconego układu. Nie miało to praktycznego znaczenia, gdyż cały Kraj Kłajpedzki stanowił już integralną część Niemiec. Pierwszym zadaniem władz niemieckich było zatarcie wszelkich śladów wskazujących na litewski charakter okręgu. Między innymi zmuszono do opuszczenia prowincji około 10 tys. Litwinów. Była to głównie ludność, która napłynęła do prowincji po 1923 r. Wysiedlono ponadto około 1,3 tys. ludności żydowskiej. Zlikwidowano wszystkie szkoły i organizacje litewskie. Utrata Kłajpedy stanowiła dla Litwy nie tylko upokorzenie polityczne, ale również przyniosła duże straty ekonomiczne, gdyż Kłajpeda stanowiła jedyny litewski port morski.

Napad hitlerowskich Niemiec na Polske wpłynął na sytuację wewnętrzną Kraju Kłajpedzkiego. Uszczelniona została granica z Litwą oraz ograniczono tranzyt litewski. Konsekwencją paktu Ribbentrop-Mołotow zawartego 28 IX 1939 r. było przyłączenie latem 1940 r. Litwy do ZSRR. Przyszłość Kłajpedy stała się obiektem pertraktacji niemieckosowieckich. Zakończone one zostały porozumieniem zawartym 10 I 1941 r. W rezultacie ZSRR uznał przyłączenie Kraju Kłajpedzkiego do Niemiec w zamian za akceptację dokonanej inkorporacji Litwy przez ZSRR. Ważną częścią tego porozumienia były uzgodnienia dotyczące wzajemnych przesiedleń ludności litewskiej i niemieckiej. Umowy te utraciły rację bytu w momencie napadu hitlerowskich Niemiec na ZSRR.

W pierwszych latach wojny Kłajpeda nie ucierpiała od bezpośrednich działań wojennych. Będąc na dalekim zapleczu, przyjęła liczne rzesze cywilnej ludności niemieckiej, chroniącej się przed nalotami aliantów. Względny spokój został przerwany w drugiej połowie 1944 r. w związku ze zbliżaniem się armii sowieckiej. W drugiej połowie października tego roku czołowe oddziały sowieckie zbliżyły się do miasta i otoczyły je od strony lądu. Przesuwanie się frontu na zachód i stopniowe opanowywanie Prus Wschodnich przez armię sowiecką było przyczyną zorganizowania przez władze niemieckie masowej ewa-

8 Problematyka związana z kryzysem politycznym w stosunkach litewsko-niemieckich, która doprowadziła w 1938 r. do ultimatum żądającego przyłączenia Kraju Kłajpedzkiego do III Rzeszy Niemieckiej, przedstawiona jest w opracowaniach A. Skrzypka (1971), S. Mikulicza (1976) oraz P. Łossowskiego (2007).

9 Kalendarium wydarzeń związanych z aneksją Kraju Kłajpedzkiego przez hitlerowskie Niemcy przedstawiono w książce P. Łossowskiego (2007).

10 W obszernym studium S. Mikulicza w formie załączników zawarte są tłumaczenia na język polski oryginalnych dokumentów dotyczących statusu prawnego Kłajpedy, w tym umowy z 16 || 1923 r. oraz układu między III Rzeszą Niemiecką a Litwą, który został zawarty 23 III 1939 r. (S. Mikulicz 1976, s. 289-331). 
kuacji ludności cywilnej. Początkowo odbywała się ona planowo, drogą kolejową. Mieszkańcy Kraju Kłajpedzkiego byli kierowani do Saksonii. W miarę zbliżania się armii sowieckiej wyjazdy nabierały charakteru spontanicznej ucieczki. Wielu mieszkańców opuszczało swoje strony rodzinne drogą morską. Pozostali próbowali się przedostać na zachód poprzez Mierzeję Kurońską. Wielu z nich po drodze zginęło.

W rezultacie kolejnej ofensywy sowieckiej 28 | 1945 r. Kłajpeda została zdobyta. Zakończył się definitywnie niemiecki okres w historii miasta i całej prowincji. W wyniku walk miasto zostało zniszczone w około 28\%, 36\% zabudowy zostało poważnie uszkodzone. Kłajpeda była w zasadzie pozbawiona mieszkańców. Nieliczni ocaleni stali się ofiarami ekscesów żołnierzy sowieckich. Z otaczających miasto obszarów wiejskich uciekła też przeważająca część ludności. Uciekali zarówno Niemcy, jak i ludność litewskojęzyczna. Ocenia się, że pozostało na miejscu około 10\% poprzedniego zaludnienia.

Bezpośrednio po zajęciu przez wojska sowieckie Kraju Kłajpedzkiego został on przyłączony do Litewskiej SRS. Przyniosto to istotne konsekwencje demograficzno-etniczne, gdyż okręg został formalnie podporządkowany władzom republikańskim w Wilnie. Tereny na południe od Niemna znalazły się w tzw. okręgu königsberskim, później przemianowanym na kaliningradzki. Włączono go do Rosyjskiej FSRR. Z punktu widzenia geopolitycznego była to wówczas niewielka różnica, gdyż cała północna część Prus Wschodnich, jak i Litwa, znalazły się w granicach ZSRR. Dla ludności miejscowej miało to pewne znaczenie, gdyż w Litewskiej SRS odnoszono się do niej bardziej liberalnie. Nie byli automatycznie poddawani - jak to się działo po południowej stronie Niemna - wysiedleniom do Niemiec. Dotyczyło to głównie ludności zamieszkałej na wsiach, gdyż miasta były już pozbawione niemieckiej ludności autochtonicznej. Po zakończeniu działań wojennych wrócito z Niemiec zaledwie kilka tysięcy uciekinierów. Były to głównie osoby pochodzenia litewskiego.

Władze republikańskie w Wilnie podjęły decyzję o zasiedleniu Kraju Kłajpedzkiego. Procesy te początkowo miały charakter spontaniczny. W pierwszych miesiącach powojennych napłynęło z pobliskiej Żmudzi do Kraju Kłajpedzkiego kilkanaście tysięcy Litwinów. Jedni przyjechali tu w celu zamieszkania, inni zaś w celach szabrowniczych. Równocześnie władze sowieckie kierowały tu wojskowych, milicjantów oraz funkcjonariuszy partyjnych i administracyjnych. Byli to przeważnie Rosjanie, gdyż ci byli najbardziej użyteczni i dyspozycyjni.

Na podstawie dekretu Rady Komisarzy Ludowych Litewskiej SRS z dnia 23 III 1946 r. rozpoczęto zorganizowaną akcję osiedleńczą. Planowano stosunkowo szybko przesiedlić około 13 tys. rodzin (około 39 tys. osób) z innych regionów Litwy. Zredukowano ten plan do 9,6 tys. rodzin, ostatecznie zaś skierowano do okręgu 5,3 tys. rodzin. Spontaniczna akcja osiedleńcza przyjęła większą skalę. Świadczą o tym dane dotyczące zaludnienia Kłajpedy. Według danych zawartych w artykule A. Saksona (2007, s. 110-111) w końcu 1945 r. mieszkało w Kłajpedzie około 6,0 tys. mieszkańców, w 1947 r. było ich już 51,0 tys. Do miasta przybyło w 1946 r. 19 tys. osób, w 1947 r. - 19,5 tys. i w 1948 - 13,8 tys. nowych przybyszy. Wiązało się to z uruchomieniem portu i zakładów przemysłowych. Do samej Kłajpedy przyjechali przybysze z całego ZSRR, zaś do mniejszych miast i wsi głównie mieszkańcy pobliskiej Litwy. Przyniosło to później istotne konsekwencje narodowościowe.

Sytuacja ludności autochtonicznej zarówno pochodzenia niemieckiego, jak i litewskiego była niezmiernie trudna. Byli oni poddawani dyskryminacji, przez władze lokalne oraz przez nowych osadników postrzegani jako Niemcy. Tak ich traktowali Rosjanie i Litwini. W przypadku tych ostatnich stereotyp utożsamiający wyznanie z narodowością (Litwin katolik, Niemiec - protestant) był na tyle ugruntowany mentalnie, że utrudniał wzajemne zrozumienie i bliższą integrację społeczną. Występujący antagonizm między ludnością napływową a nieliczną autochtoniczną stał się powodem stopniowej emigracji tej ostatniej 
do Niemiec. Trudne warunki ekonomiczne też stymulowały wyjazdy. Wyjeżdżały głównie osoby pochodzenia litewskiego, zamieszkujące tereny wiejskie, gdyż tylko tacy uchylili się od ucieczki w końcowej fazie wojny ${ }^{11}$.

Według ocen dotyczących stanu z 1 I 1946 r. na obszarze Kraju Kłajpedzkiego znajdowało się 55,5 tys. mieszkańców (w 1938 r. - 152,8 tys.). O liczebności ludności autochtonicznej świadczą dane o liczbie gospodarstw rolnych będących jeszcze $w$ ich posiadaniu. Takich gospodarstw w powiecie kłajpedzkim było 1353, w powiecie Szyłokarczma - 1055, a w powiecie Pageje - 245. Mieszkało w nich 7,8 tys. mieszkańców (A. Sakson 2007, s. 122). Poprzez wprowadzenie kolektywizacji zostali przekształceni w robotników najemnych, co przyniosto ich stopniową marginalizację i totalną pauperyzację.

W miastach, zwłaszcza w Kłajpedzie, nastąpiły szybkie procesy rusyfikacji i sowietyzacji. W zakładach pracy, a zwłaszcza w porcie, język rosyjski wypierał litewski. Nastąpiły równocześnie typowe procesy ruraryzacji miasta. Wynikało to z napływu ludności pochodzenia wiejskiego, której trudno było się zaadaptować do warunków miejskich.

Na przełomie lat 40. i 50. sytuacja stopniowo się stabilizowała. Cechą znamienną był szybki wzrost zaludnienia. Był on rezultatem nie tyle powojennej kompensacji urodzeń, ile przede wszystkim napływu ludności spoza okręgu kłajpedzkiego. Przyjeżdżali Litwini z etnicznej Litwy, jak i przedstawiciele wszystkich narodów ZSRR, w tym głównie narodowości rosyjskiej. Ze względu na swoje dogodne usytuowanie Kłajpeda stała się dużym ośrodkiem przemysłowym i portowym. Powstanie nowych miejsc pracy przyczyniło się do wzrostu budownictwa mieszkaniowego i rozwoju miasta. Kłajpeda stała się po Wilnie i Kownie największym ośrodkiem miejskim Litewskiej SRS. Skali przyrostu demograficznego i zmian struktury narodowościowej dowodzą dane zamieszczone w Tabeli 2.

Nawet na tle szybkich procesów urbanizacyjnych, które zachodziły w ówczesnej Litwie, wzrost ludnościowy Kłajpedy był wyjątkowy. W okresie analizowanych 30 lat liczba ludności miasta zwiększyła się o 113 tys. mieszkańców. Uległ niewielkiemu powiększeniu odsetek ludności narodowości litewskiej. Mniejszość rosyjska była bardzo liczna i to ona odgrywała najważniejszą rolę polityczną. Pozostałe mniejszości narodowe posługiwały się przeważnie językiem rosyjskim, co też wpływało na oblicze etniczne miasta. Spis w zasadzie nie odnotował osób deklarujących narodowość niemiecką. Pozostała nieliczna ludność autochtoniczna z obawy przez dyskryminacją podała w spisie narodowość litewską. Na terenach wiejskich zachodziły stopniowe procesy lituanizacji. Mniejszości słowiańskie, w tym rosyjska, odgrywały na wsi rolę nieznaczną i na tych terenach dominował język litewski.

Tabela 2. Struktura narodowościowa Kłajpedy w okresie 1959-1989

\begin{tabular}{|l|r|r|r|r|r|r|r|}
\hline \multirow{2}{*}{ Rok } & \multirow{2}{*}{$\begin{array}{c}\text { Liczba } \\
\text { ludności }\end{array}$} & \multicolumn{2}{|c|}{ W tym: } \\
\cline { 3 - 8 } & & \multicolumn{2}{|c|}{ Litwini } & \multicolumn{2}{c|}{ Rosjanie } & \multicolumn{2}{c|}{ pozostali } \\
\cline { 3 - 8 } & 89923 & 49666 & 55,2 & 32072 & 35,6 & 8185 & 9,2 \\
\hline 1959 & 140012 & 85216 & 60,8 & 43282 & 30,9 & 11514 & 8,3 \\
\hline 1970 & 176648 & 108707 & 61,5 & 52205 & 29,5 & 15736 & 9,0 \\
\hline 1979 & 202929 & 127757 & 63,0 & 57204 & 28,2 & 17968 & 7,8 \\
\hline 1989 & & &
\end{tabular}

Źr ó d † o: 1959 - Itogi wsiesojuznoj pieriepisi nasielienija, Goskomstat, Moskwa 1963;

1970 - Itogi wsiesojuznoj pieriepisi nasielienija, Goskomstat, Moskwa 1972;

1979 - Itogi wsiesojuznoj pieriepisi nasielienija, Goskomstat, Moskwa 1981;

1989 - Nacjonalnyj sostaw nasielienija SSSR, Goskomstat, Moskwa 1991.

11 Warunki życia ludności autochtonicznej, jak i ogólną sytuację społeczną w Kraju Kłajpedzkim bezpośrednio po wojnie szczegółowo opisał A. Sakson (2007). Nie wymagają one dokładniejszej analizy faktograficznej. 
Przełomowym wydarzeniem dla całej Litwy, w tym również dla Kraju Kłajpedzkiego, był rozpad ZSRR i obalenie komunizmu. Litwa uzyskała podmiotowość polityczną. Odzyskanie niepodległości i objęcie władzy administracyjnej przez narodowe siły litewskie nie tylko doprowadziło do zmian ustrojowych, ale stało się początkiem przeobrażeń demograficzno-narodowościowych. Status ludności litewskiej i rosyjskiej uległ diametralnej zmianie. Litwini poczuli się gospodarzami kraju i zaczęli odgrywać dominującą rolę polityczną. Rosjanie stali się niepotrzebną mniejszością narodową. Wielu działaczy sowieckich, przeważnie narodowości rosyjskiej, utraciło pracę i znaczenie. Wraz z likwidacją baz wojskowych zaczął opuszczać Litwę rosyjski korpus oficerski oraz wielu emerytowanych wojskowych. Restrukturyzacja gospodarki, a zwłaszcza upadek wielkich przedsiębiorstw przemysłowych, pozbawiła pracy wielu specjalistów i robotników rosyjskich. Tysiące funkcjonariuszy administracyjnych i partyjnych nieznających języka litewskiego zostało zmuszonych do wyjazdu z Litwy. Ze względu na wysoki udział ludności rosyjskiej w Kłajpedzie skala migracji przybrała tu większy zakres niż $w$ innych miastach litewskich. Nie dotyczyło to jedynie Rosjan, gdyż przedstawiciele innych narodów sowieckich (np. Ukraińcy czy Białorusini) też byli nakłaniani do opuszczenia swoich miejsc zamieszkania. Główną rolę odgrywały tu względy ekonomiczne i prestiżowe, ale ogólna atmosfera polityczna stymulowała decyzje migracyjne. Stosunek Litwinów do Rosjan jako byłych „okupantów” też utrudniał adaptację ludności rosyjskojęzycznej.

Należy tu zaznaczyć, że Litwa, będąc krajem demokratycznym, nie była areną jakichkolwiek ekscesów antyrosyjskich. Niemniej, warunki społeczne utrudniały szybką naturalizację ludności nielitewskiej. Pomimo że wyjazdy ludności rosyjskojęzycznej z okręgu kłajpedzkiego objęły kilkanaście tysięcy mieszkańców, to jednak przeważająca część napływowej ludności rosyjskojęzycznej postanowiła nie opuszczać Litwy. Przyjęła obywatelstwo litewskie i starała się dopasować do nowych warunków życia. Wyższy standard życia na Litwie niż w innych republikach postsowieckich umacniał lojalność wobec państwowości litewskiej. Można założyć, że u młodego pokolenia Rosjan urodzonych w Kłajpedzie powstanie dążność do pełnej asymilacji z otoczeniem litewskojęzycznym. Celowe działania władz litewskich, zwłaszcza w zakresie szkolnictwa będą też sprzyjały procesowi lituanizacji.

Zachodzące przemiany demograficzno-etniczne odzwierciedliły się w nowym spisie ludności zrealizowanym przez władze litewskie w 2001 roku. Nie dysponujemy informacjami statystycznymi dla historycznego Kraju Kłajpedzkiego. Jeszcze w okresie sowieckim nastąpiły istotne zmiany administracyjne. Do rejonu Kłajpeda i Szyłokarczma włączono dodatkowo obszar należący dawniej do Żmudzi. Statystyczna jednostka odniesienia obejmuje tereny znacznie bardziej rozlegte od tych, jakie rozpatrywano $w$ analizie dotyczącej okresu międzywojennego. Nie wpłynie to jednak w poważniejszym stopniu na ogólne wnioski merytoryczne. Współczesny okręg kłajpedzki obejmuje dwa miasta: Kłajpedę i Nidę ${ }^{12}$ oraz trzy rejony: Kłajpeda, Szyłokarczma i Pojegi. Zaludnienie wyodrębnionego terytorium wyniosło w 2001 r. 309,1 tys., w tym blisko 250,0 tys. zadeklarowało narodowość litewską (Tabela 3).

W okresie międzyspisowym (1989-2001) zaludnienie miasta Kłajpedy obniżyło się z 202,9 tys. do 192,9 tys. Było to efektem wspomnianej już emigracji ludności rosyjskojęzycznej, która nie była w stanie zaadaptować się do nowych warunków w suwerennym państwie litewskim. Liczba rodowitych Rosjan zmniejszyła się w Kłajpedzie jeszcze bardziej, gdyż w 1989 r. spis sowiecki wykazał 57,2 tys., zaś najnowszy spis litewski - 41,1 tys.

12 Nida (lit. Neringa, niem. Nidden) jest niewielką miejscowością wczasową położoną na Mierzei Kurońskiej. Ma odrębny status administracyjny. 
Tabela 3. Struktura narodowościowa okręgu kłajpedzkiego w 2001 roku

\begin{tabular}{|l|r|r|c|r|r|r|r|r|r|}
\hline \multirow{3}{*}{ Miasto lub rejon } & \multirow{2}{*}{$\begin{array}{c}\text { Liczba } \\
\text { ludności }\end{array}$} & \multicolumn{9}{|c|}{ Witwini } & \multicolumn{2}{|c|}{ Rosjanie } & \multicolumn{2}{c|}{ Niemcy } & \multicolumn{2}{c|}{ pozostali } \\
\cline { 3 - 10 } & & \multicolumn{1}{|c|}{ ogółem } & \% & ogółem & \multicolumn{1}{c|}{$\%$} & ogółem & $\%$ & \multicolumn{1}{c|}{ ogółem } & $\%$ \\
\hline m. Kłajpeda & 192954 & 137557 & 71,3 & 41100 & 21,3 & 399 & 0,2 & 13898 & 7,2 \\
\hline m. Nida & 2386 & 2206 & 92,5 & 124 & 5,2 & 5 & 0,2 & 51 & 2,1 \\
\hline r. Kłajpeda & 46220 & 44830 & 97,0 & 802 & 1,7 & 148 & 0,3 & 440 & 1,0 \\
\hline r. Szyłokarczma & 55302 & 53279 & 96,4 & 1078 & 1,9 & 394 & 0,7 & 551 & 1,0 \\
\hline r. Pojegi & 12208 & 11881 & 97,3 & 177 & 1,4 & 32 & 0,3 & 118 & 1,0 \\
\hline Ogółem & 309070 & 249753 & 80,8 & 43281 & 14,0 & 978 & 0,3 & 15058 & 4,9 \\
\hline
\end{tabular}

Ź r ó d † o: Gyventojai pagal lyți, amžių, tautybę ir tikybą [Population by Sex, Age, Ethnicity and Religion], Statistikos, Departamentas, Vilnius 2002

ludności rosyjskiej. Odzwierciedliło się to również w jej udziale procentowym (1989 r. 28,2\%, 2001 r. - 21,3\%). Wzrósł natomiast wyraźnie odsetek ludności litewskiej. Zmiany poza Kłajpedą były już znacznie mniejsze, gdyż tam zawsze liczba ludności rosyjskiej była znikoma. Z przedstawionych danych statystycznych wynika, że w rezultacie zmian politycznych nasilał się proces lituanizacji miasta i okręgu kłajpedzkiego. Pierwszy raz po wojnie ujawniła się w spisie pewna liczba ludności narodowości niemieckiej (około 1,0 tys.). Z wyjątkiem miasta Kłajpedy, w którym skupia się jeszcze znaczna liczba ludności nielitewskiej, pozostały obszar stał się jednolity narodowo i nie różni się etnicznie od sąsiadującej z okręgiem litewskiej Żmudzi.

Analizowany spis ludności po raz pierwszy od blisko 80 lat uwzględnił na Litwie strukturę religijną mieszkańców. Spisywani podawali swoją przynależność wyznaniową. Mogli również uchylić się od odpowiedzi bądź określić się jako ateiści lub agnostycy. Dla oceny etniczności te wyniki są bardzo ważne, gdyż wskazują na rodowód ludności. Prawie zawsze katolicy to ludność napływowa pochodzenia litewskiego, sporadycznie polskiego. Ludność prawosławna w przeważającej większości obejmowała Rosjan, Białorusinów i Ukraińców, którzy napłynęli w okresie sowieckim. Nie budzi wątpliwości fakt, że ewangelicy to przeważnie potomkowie rodowitych „kłajpedzian”, którzy przetrwali wbrew wszelkim prześladowaniom na swojej ziemi rodzimej. Jedynie bardzo nieliczni ewangelicy mogą być rdzennymi Litwinami, którzy napłynęli po wojnie do okręgu kłajpedzkiego. Wśród niewierzących oraz tzw. nieokreślonych mogą być przedstawiciele wszystkich grup narodowościowych. Wydaje się jednak, że przeważa tam ludność napływowa, głównie pochodzenia rosyjskiego. Wśród powojennych migrantów narodowości rosyjskiej wieloletnia propaganda ateistyczna była bardziej skuteczna niż wśród rdzennych Litwinów. Byli oni również bardziej oderwani od swego rodowodu prawosławnego i ulegali szybkiej laicyzacji. Rodowici litewscy katolicy byli bardziej przywiązani do pryncypiów swojej wiary, a jej prześladowania w okresie sowieckim przynosiły często wręcz odwrotne rezultaty. Utożsamianie litewskości z katolicyzmem stanowiło rękojmię przetrwania narodu litewskiego. Przyjmując te założenia, łatwiej interpretować wyniki spisu odniesione do składu konfesjonalnego ludności okręgu kłajpedzkiego (Tabela 4).

Ponad 2/3 ludności okręgu zadeklarowało przynależność do Kościoła rzymskokatolickiego. Na obszarach wiejskich odsetek wierzących katolików znacznie przekracza 80\% ogólnego zaludnienia. Dane narodowościowe wykazały w mieście Kłajpedzie obecność Rosjan w liczbie 41 000, Ukraińców - 4652 i Białorusinów - 3606 osób. Trzy wymienione narody obejmowały łącznie 49358 mieszkańców. Równocześnie uznało się za prawo- 


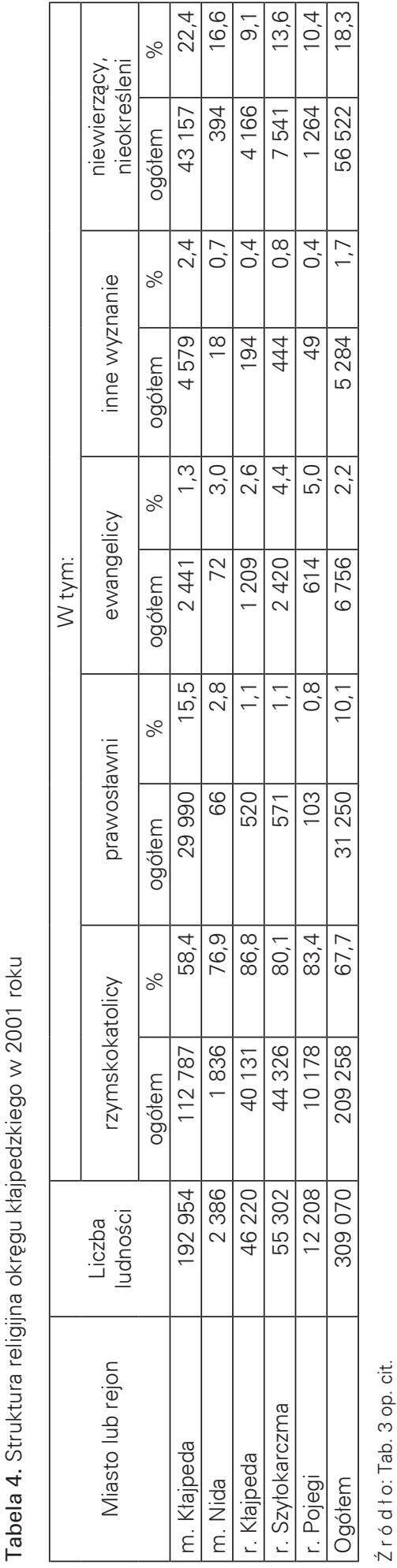

sławnych 29990 osób. Wynika z tego, że wśród migrantów pochodzenia słowiańskiego mamy wiele osób niewierzących, niezwiązanych ze wspólnotą prawosławną. Bardzo ważne z punktu widzenia poznawczego są informacje statystyczne o liczebności ludności protestanckiej. Na rozpatrywanym obszarze uznało się za wyznawców Kościoła luterańskiego i, w dużo mniejszym stopniu, kalwińskiego, tącznie 6756 osób. Stanowiło to 2,2\% ogólnego zaludnienia. Można przyjąć, że są to pozostałości byłej ludności autochtonicznej. Wspólnoty protestanckie koncentrują się W Kłajpedzie, gdzie Kościół ewangelicko-augsburski grupuje 2043, a Kościół ewangelicko-reformowany 398 wyznawców. W rejonie Szyłokarczma do Kościoła luterańskiego należy 2348, w rejonie kłajpedzkim - 1165 i w rejonie Pageje -610 wiernych. Natomiast w tych 3 rejonach do Kościoła kalwińskiego należy jedynie 82 wyznawców. Z przedstawionych informacji statystycznych wynika, że wspólnoty protestanckie są nieliczne i terytorialnie rozproszone. Biorąc pod uwage fakt, że do II wojny światowej około 95\% mieszkańców kraju kłajpedzkiego deklarowało przynależność do Kościoła protestanckiego, zaprezentowane dane wskazują na całkowitą zmianę sytuacji nie tylko narodowościowej, ale i religijnej.

W rezultacie przesiedleń powojennych oraz migracji politycznych i ekonomicznych nastąpiła nie tylko lituanizacja, ale i katolicyzacja Kraju Kłajpedzkiego. Nastąpiła prawie całkowita wymiana ludności - zanik żywiołu niemieckiego oraz litewskojęzycznego, ewangelickiego, deklarującego związek ze wspólnotą niemiecką. Na miejsce ludności protestanckiej zjawiła się ludność katolicka oraz, częściowo, rosyjska lub rosyjskojęzyczna rodowodu prawosławnego, lecz poddawana przez dziesięciolecia intensywnej indoktrynacji ateistycznej. Można przewidywać, że w miarę upływu czasu ludność rosyjskojęzyczna, będąca reliktem okresu sowieckiego, będzie stopniowo ulegała marginalizacji. Młode generacje Rosjan, Białorusinów czy Ukraińców będą poddawane silnym procesom kulturowej i językowej lituanizacji. W stosunkowo niedługim czasie ukształtuje się jednorodny etniczny obszar litewsko-katolicki, niewiele różniący się swoją specyfiką demograficzno-społeczną od pobliskich terenów należących do historycznej Żmudzi. 
Mówiąc o zmianach demograficzno-etnicznych, nie można pominąć konsekwencji geopolitycznych dla Kraju Kłajpedzkiego, który ma wyjątkowe położenie strategiczne. Usytuowany jest nad Zalewem Kurońskim, przy ujściu Niemna, w pobliżu Kaliningradu, będącego wielką bazą militarną Rosji. Region ten, będąc w granicach Niemiec lub Rosji, byłby barierą oddzielającą Litwę od morza. Poprzez szeroki dostęp do morza i dysponując dużym portem morskim w Kłajpedzie, Litwa może łatwiej realizować swoje cele polityczne i gospodarcze. Przestała był krajem lądowym, stając się państwem mocno osadzonym nad Bałtykiem. Było to pragnienie wielu pokoleń patriotów litewskich, które $w$ zasadzie zostało zrealizowane w pełni dopiero w 1991 r., gdyż odzyskanie Kłajpedy w 1945 r. było nieodłącznie związane z utratą niepodległości.

LITERATURA

Eberhardt P., 1997, Przemiany narodowościowe na Litwie, „Przegląd Wschodni”, Warszawa.

Lewicki S., 1979, Aneksja bez wystrzału, Wydawnictwo MON, Warszawa.

Łossowski P., 2007, Kłajpeda kontra Memel. Problem Kłajpedy 1918-1939-1945, Wydawnictwo Neriton, Instytut Historii PAN, Warszawa.

Mikulicz S., 1976, Kłajpeda w polityce europejskiej 1918-1939, Książka i Wiedza, Warszawa.

Ochota J., 1932, Zatarg litewsko-niemiecki w Kłajpedzie, "Sprawy Narodowościowe", R. VI, nr 2-3, s. 269-279, Warszawa.

Sakson A., 2007, Kraj Kłajpedzki. Zmiany ludnościowe 1945-1990, "Przegląd Zachodni”, T. LXIII, nr 3, s. 105-125, Poznań.

Skrzypek A., 1971, Kłajpeda jako zagadnienie międzynarodowe, "Dzieje Najnowsze", R. III, z. 3, s. 55-77, Warszawa.

Srokowski S., 1929, Prusy Wschodnie. Kraj i ludzie, Nakładem Księgarni F. Hoesicka, Warszawa.

Srokowski S., 1937, Ludność Prus Wschodnich, Główna Drukarnia Wojskowa, Warszawa. Staniewicz W., 1924, Sprawa Kłajpedy, Wileńskie Biuro Informacyjne, Wilno.

Szostakowska M., 1992, Litwini-prusacy w latach 1918-1933 w świetle materiałów Archiwum Akt Nowych w Warszawie, [w:] A. Skrzypek, S. Szostakowski (red.), Polacy, Litwini, Niemcy w kręgu wzajemnego oddziaływania, "Studia i Materiały”, Wyższa Szkoła Pedagogiczna, nr 37, s. 105-117, Olsztyn.

Szostakowski S., 1992, Wschodniopruskie to czasopisma "Auszra" (1883-1886), [w:] A. Skrzypek, S. Szostakowski (red.), Polacy, Litwini, Niemcy w kregu wzajemnego oddziaływania, "Studia i Materiały”, Wyższa Szkoła Pedagogiczna, nr 37, s. 9-26, Olsztyn.

Wielhorski W., 1932, Procesy narodowościowe w Prusach Wschodnich, "Sprawy Narodowościowe", R. VI, nr 1, s. 28-54, Warszawa.

Wielhorski W., 1938, Litwa Współczesna, Wojskowy Instytut Geograficzny, Warszawa. 


\section{POPULATION TRANSFORMATIONS IN THE KLAIPEDA REGION \\ IN THE 2OTH CENTURY}

\section{Sum mary}

The Klaipeda Region is now an integral part of Lithuania. This was not, however, always the case; the region has a strong German history. (Its historical German name was Memelland, while in Lithuanian it was called Klaipedos Krastas.) Until 1525, the Klaipeda Region belonged to the Teutonic Order, but later changed hands several times. Initially, it belonged to the Duchy of Prussia (until 1701; and until 1657 was dependent as a fief of Poland), was later controlled by the Kingdom of Prussia (until 1871), and then finally became part of the German Empire (until 1919). For Germans, the province was a historical part of Eastern Prussia until 1945. For Lithuanians, the Klaipeda Region, as well as the area located along the north-eastern part of East Prussia on the south bank of the Neman River, was known as Little Lithuania (Lithuania Minor). The Lithuanians considered this territory to be their own ethnic land, which was wrongfully subjected to gradual Germanization. Before World War II this area was inhabited by Protestants who spoke Lithuanian or German. The 1920 census lists the territory's population at 150,700 , of which 71,000 declared German to be their first language, while 67,000 declared Lithuanian.

The article first discusses the historical and political background of events in the Klaipeda Region in the first half of the 20th century. Next the author analyzes in a dynamic approach the demographic and ethnic structure of the population. His attention is later focused on the period of World War II when the province was incorporated into the Lithuanian Soviet Socialist Republic. In the Soviet period, a major part of the local population was expelled to Germany, while the remaining residents were identified as either Lithuanians or Russians such that the province was no longer dominated by the Protestant and German speaking population. The final part of the article deals with the present demographic and national situation. As a result of the postwar political and economic migrations, a majority of the people in the province now identify themselves as Lithuanian and Catholic. Lithuania, owing to the port of Klaipeda, has now an unrestricted access to sea.

Keywords: Klaipeda, Lithuanians, Germans, demography 